\title{
JAZF1/SUZ12 Fusion Gene
}

National Cancer Institute

\section{Source}

National Cancer Institute. AAZF1/SUZ12 Fusion Gene. NCI Thesaurus. Code C99707.

A fusion gene that results from a chromosomal translocation $t(7 ; 17)(p 15 ; q 21)$ that fuses the first 3 exons of the JAZF1 gene to the last 15 exons of the SUZ12 gene. This rearrangement is associated with endometrial stromal neoplasms. 